\title{
KESULITAN MEMBACA KATA ANAK DISLEKSIA USIA 7-12 TAHUN DI SEKOLAH SDN 1 SANGSIT KECAMATAN SAWAN KABUPATEN BULELENG BALI
}

\author{
Luh Budiani $^{1}$, A.A Marhaeni ${ }^{2}$ Putrayasa $^{3}$ \\ Program Studi Pendidikan Dasar, Program Pasca Sarjana \\ Universitas Pendidikan Ganesha Singaraja, Indonesia
}

Email : jeroputupuspa17@gmail.com,marhaeni@pasca.undiksha.ac.id ibputra@gmail.com

\begin{abstract}
ABSTRAK
Penelitian ini bertujuan mendeskripsikan :(1) kesulitan membaca kata disleksia (2) kendala- kendala dikelas satu SDN 1 Sangsit yang menjadi penyebab disleksia,(3) upaya-upaya yang dilakukan guru untuk menangani disleksia. Rancangan penelitian ini adalah kualitatif. Teknik pengumpulan data dilakukan dengan tes, checklist,wawancara. Hasil penelitian ini menunjukkan bahwa :(1) terdapat kesulitan-kesulitan membaca kata dikelas satu seperti sulit membaca /memproses fonologi sehingga kurang mampu membaca (decode), mengeja kata (encode), berbicara (syintax) (2)Terdapat kendalakendala penyebab disleksia yaitu faktor gen (hereditas), lingkungan, cahaya yang mengakibatkan sindrom irlen, kerusakan neorologis, artikulasi (3) terdapat upaya-upaya yang dilakukan guru untuk siswa disleksia seperti intervensi, toleransi, dispensasi, multisensori, metode gilingham, Clinical teaching, alat bantu seperti buku-buku bergambar, remidial teaching, memperhatikan perkembangan sosial emosional anak agar siswa disleksia tidak mengalami demotivasi belajar dan kefrustasian yang bisa membawanya pada kesulitan-kesulitan lain.

Kata-kata kunci : Kesulitan membaca kata, disleksia
\end{abstract}

\begin{abstract}
This study aims to describe: (1) difficulties in reading the word dyslexia (2) constraints in the first class of Sangsit 1 Elementary School which are the cause of dyslexia, (3) efforts made by teachers to deal with dyslexia. The design of this study is qualitative. Data collection techniques are carried out by tests, checklists, interviews. The results of this study indicate that: (1) there are difficulties in reading words in the first grade such as difficulty reading / processing phonology so that they are less able to read (decode), spell words (encode), speak (syintax) (2) There are obstacles to dyslexia namely genes (heredity), environment, light that cause irlen syndrome, neorological damage, articulation (3) there are efforts made by teachers for dyslexic students such as intervention, tolerance, dispensation, multisensory, millingham methods, clinical teaching, assistive devices such as picture books, remidial teaching, pay attention to children's social emotional development so that dyslexic students do not experience the demotivation of learning and frustration that can lead to other difficulties.
\end{abstract}

Key words: Difficulty reading words, dyslexia 


\section{PENDAHULUAN}

Pada umumnya penderita disleksia kesulitan mengeja kata, membaca,menulis, berbicara,serta mendengarkan suara orang lain.

Mereka kurang mampu menganalisisis maksud keseluruhan kata-kata dan mencampurkan bunyi/suara dalam kata-kata. Disleksia adalah salah satu masalah dalam masalah gangguan belajar spesifik. Disleksia adalah suatu gangguan proses belajar,dimana seseorang mengalami kesulitan membaca,menulis atau mengeja dengan kata lain,disleksia tidak memengaruhi dan dipengaruhi oleh tingkat kecerdasan seseorang.karena bersifat kompleks belajar membaca juga dianggap sulit bagi anak-anak yang mengalami gangguan disleksia.

Pengalaman mengajar di SDN 1 Sangsit menunjukkan bahwa ada beberapa anak yang mengalami kesulitan membaca baik dikelas rendah maupun dikelas tinggi. Ketika anak-anak memasuki usia 712 tahun, kemampuan membaca dan menulis adalah dua hal yang sangat diperhatikan oleh para orang tua karena kemampuan tersebut wajib dimiliki anak-anak yang ingin bersekolah di Sekolah Dasar (SD). Untuk menilai kemampuan membaca dan menulis, pengelola SD yang mengadakan tes kemampuan tersebut sebagai bahan pertimbangan menerima anak-anak yang akan masuk sekolah pada tahun 2011 sejak peneliti bertugas mengajar di SDN 1 Sangsit. Akan tetapi tahun 2018 penerimaan peserta didik baru (PPDB) di SDN 1 Sangsit tidak dilaksanakan penyaringan melalui tes membaca dan menulis maupun berhitung seperti yang dilakukan tahun sebelumnya sehingga tanpa diseleksi menyebabkan banyak siswa yang belum bisa membaca dikelas satu dengan didukung oleh keluhan para guru kelas,terutama guru kelas I ada 7 anak yang mengalami kesulitan membaca kata,begitu juga dikelas 2A dua orang belum bisa membaca,dikelas $3 \mathrm{~A}$ ada temuan satu orang anak mengalami kesulitan membaca,dikelas 4B temuan 4 murid yang belum bisa membaca lancar kata anak pada usia 7-12 tahun.Hal itulah yang kiranya menyebabkan peneliti berniat melakukan penelitian tentang kesulitan membaca,sehingga peneliti mempunyai khawatiran, jika anak-anak tersebut kemungkinan mengalami gangguan dalam hal mebaca kata. Peneliti fokus pada subyek kelas satu dalam penelitian.

Gangguan dalam pelajaran membaca dapat diketahui gejalanya dengan mudah yaitu anak tidak mengenal simbol huruf. Huruf-huruf dan kata-kata adalah figur-figur yang mempunyai bunyi-bunyi tertentu, serta dengan berbagai bunyian secara bersama-sama akan membentuk arti. Dalam pelajaran membaca faktor berikut turut bermain seperti kesadaran adanya bunyian dalam bicara adalah wujud dari simbolsimbol huruf yang diucapkan, mampu mendengarkan dengan baik akan adanya bagaimana sebuah kata berbunyi. Dapat melihat dengan baik perbedaan bentuk huruf -huruf dan kedudukan huruf-huruf itu. Gangguan tersebut mengakibatkan kesulitan-kesulitan seperti mengeja, kekurangmampuan decoding dalam pembelajaran membaca,gangguan yang parah dalam makna bahasa, minim dalam hal kesadaran pencandraan auditif bunyian (fonem), meraba-raba bacaan, minim intonasi (Endang,2017:44) 


\section{KAJIAN PUSTAKA, KONSEP, TEORI DAN MODEL PENELITIAN}

Bahan yang dikaji atau yang ditelaah pada penelitian ini adalah bersumber dari dua buku disleksia pertama yang ditulis oleh Olivia Bobby dan Vica Valentina, ke dua Endang Widyoroni dan Julia Maria Van Tiel.

\section{Kajian Hasil Penelitian Yang Relevan}

Berikut adalah beberapa penelitian yang relevan dan terkait dengan Kesulitan membaca kata anak disleksia usia 7-12 tahun di SDN 1 Sangsit Kecamatan Sawan Kabupaten Buleleng Bali :

1. Intan amalia, Kesulitan membaca kata anak disleksia usia 7-12 tahun di sekolah inklusif. Galuh handayani Surabaya, kajian psikolinguistik. Tahun 2016

2. Nurul Hidayanti Rofiah, Proses identifikasi : Mengenal anak kesulitan belajar tipe disleksia bagi guru sekolah dasar inklusi. Tahun 2015

3. Fitri Arianti, Penggunaan metode fonik (phonic method) untuk meningkatkan kemampuan membaca anak disleksia di kelas 1 SD Negeri 187/1 Teratai FKIP Universitas Jambi. Tahun 2016

\section{KONSEP}

Disleksia-kesulitan

disleksia,kendala

Disleksia-upaya-upaya disleksia.

\section{TEORI}

Menurut(Endang,2017:69)

Disleksia adalah suatu alternatif istilah untuk menunjukkan pola kesulitan belajar dengan karakteristik adanya problem rekognisi dan akurasi

kiri lebih besar sedangkan pada penderita disleksia belahan otaknya simetris.Dengan kata lain belahan otak kanan penderita disleksia menjadi lebih besar dari pada otak kanan manusia pada umumnya, sementara belahan kirinya lebih kecil daripada otak kiri manusia pada umumnya.

Bagian otak kiri berkaitan dengan urutan, cara berpikir linier, dan kemampuan berbahasa. Dengan ukuran sisi kiri yang lebih kecil daripada manusia normal maka dengan sendirinya area bahasa penderita disleksia berbeda pula. Inilah yang membuat kemampuan mereka memproses informasi linguistik/bahasa jadi berbeda.

Para orang tua dan pengajar pun dapat lebih siap untuk menangani anak-anak yang diduga menderita disleksia. Semakin cepat diprediksi, semakin cepat pula perawatan (treatment) untuk anakanak disleksia dimulai. Dengan perawatan yang baik dan tepat anak-anak disleksia akan tetap dapat belajar dan tumbuh dengan baik, seperti anak-anak lainnya.

Atas dasar yang telah

dikemukakan mengenai

permasalahan yang telah dikemukakan tentang disleksia diatas maka peneliti tertarik untuk mengadakan penelitian dengan judul : Kesulitan membaca kata anak disleksia usia 7-12 tahun disekolah SDN 1 Sangsit Kecamatan Sawan Kabupaten Buleleng Bali. 


\section{Rumusan Masalah}

Berdasarkan latar belakang yang telah diuraikan,maka masalah dapat dirumuskan sebagai berikut:

1. Apakah kesulitan-kesulitan membaca yang terdapat pada siswa di SDN 1 Sangsit?

2. Apakah kendala-kendala yang menyebabkan anak-anak belum bisa membaca kata dengan baik dan benar pada siswa di SDN 1 Sangsit?

3. Bagaimana solusi dalam upaya penanganan bagi siswa yang mengalami kesulitan membaca disleksia?

\section{Tujuan Penelitian}

Berdasarkan permasalahan seperti yang telah dikemukakan di atas,tujuan dari penelitian tugas akhir ini adalah :

1. Untuk menganalisis kesulitankesulitan membaca di SDN 1 Sangsit

2. Mencari kendala-kendala yang mempengaruhi anak-anak yang belum bisa membaca dengan baik dan mencari ciri-ciri anak yang mengalami disleksia di SDN 1 Sangsit

3. Mencari solusi untuk menangani atau mengatasi anak-anak yang mengalami kesulitan membaca/disleksia di SDN 1 Sangsit

\section{METODE PENELITIAN}

Rancangan penelitian ini adalah kualitatif. Prosedur penelitian dilakukan dengan tahap pertama observasi, wawancara, dokumentasi tahap kedua dengan tes, cheklist, wawancara. Populasi penelitian ini dari siswa kelas satu, dengan jumlah sampel sebanyak 7 orang. Metode pengumpulan data dilakukan dengan tes, checklist,wawancara. Analisis data penelitian ini dengan metode deskriptif.

\section{HASIL DAN PEMBAHASAN}

Penelitian tentang kesulitan membaca kata anak disleksia di SDN 1 Sangsit , Kecamatan Sawan kabupaten Buleleng dimulai tanggal 25 April 2019 terhitung sejak aktivitas perijinan sampai dengan pengambilan data. Data yang diperoleh dari penelitian ini adalah data tentang siswa yang mengalami kesulitan membaca disleksia di SDN 1 Sangsit. Pada saat menghadap kepala sekolah peneliti disambut dengan senang hati untuk melakukan penelitian. Pada penelitian ini peneliti menggunakan penelitian kualitatif. Data diperoleh Pertama Observasi, Wawancara dan dokumentasi, kedua tes ,checklist, wawancara.

Penelitian ini dilakukan disebuah Sekolah Negeri 1 Sangsit yang berlokasi di Desa Sangsit Kecamatan Sawan Kabupaten Buleleng Bali

Proses menemukan subyek disleksia diawali dengan adanya tugas studi kasus dan memilih tempat. Tempat yang dipilih adalah SD $\mathrm{N} 1$ sangsit kecamatan sawan Kota singaraja peneliti mengobservasi dan mengidentiikasi siswasiswi yang bermasalah dalam belajarnya. Dari hasil observasi dan identifikasi yang dilakukan oleh peneliti diketahui siswasiswi yang menujukkan adanya masalah belajar yang sedang dihadapi subyek disleksia dan menurut peneliti masalah tersebut perlu segera diselesaikan. Dari masalah yang dimiliki subyek disleksia, peneliti meminta guru kelas 1a untuk mengangkat masalah yang dihadapi oleh subyek disleksia untuk dijadikan studi kasus.kesulitan ditemukan dari ortografi membaca kata contoh : 


\begin{tabular}{|c|c|c|c|}
\hline NO & $\begin{array}{l}\text { Kata } \\
\text { yang } \\
\text { dibaca }\end{array}$ & Ortografi & $\begin{array}{l}\text { Tuturan } \\
\text { siswa }\end{array}$ \\
\hline 1 & tempat & tem $\cdot p a t$ & [tempat] \\
\hline 2 & tinggal & ting $\cdot g a l$ & [tiga] \\
\hline 3 & hewan & $h e \cdot w a n$ & [hahehe] \\
\hline 4 & beni & $b e-n i$ & [bene] \\
\hline 5 & tentang & ten'tang & [teta] \\
\hline 6 & hewan & he.wan & [hewa] \\
\hline 7 & gambar & gam bbar & [ama] \\
\hline 8 & tempat & tem.pat & [tema] \\
\hline 9 & tinggal & ting $\cdot g a l$ & [tiga] \\
\hline 10 & ditempat & ditem $\cdot p a t$ & [dite] \\
\hline 11 & didarat & $d i \cdot d a \cdot r a t$ & [dida] \\
\hline 12 & ayam & $a \cdot y a m$ & [ayah] \\
\hline 13 & kelinci & $\mathrm{ke} \cdot \mathrm{lin} \cdot \mathrm{ci}$ & [keci] \\
\hline 14 & hidup & $h i \cdot d u p$ & [hidu] \\
\hline 15 & di air & di air & [dira] \\
\hline 16 & contoh & con'toh & [conta] \\
\hline 17 & katak & $k a \cdot t a k$ & [katah] \\
\hline
\end{tabular}

Mengeja,berbicara,menganalisa makna kata dan mencampurkan bunyi huruf $b$ dan d dalam kata-kata.

Kendala-kendala yang ditemukan menjadi penyebab disleksia subyek adalah Faktor gen, faktor kerusakan neurologis, alat-alat ucap, memadukan huruf, kendala penglihatan akibat sindrom irlen

Upaya yang dapat dilakukan untuk siswa yang mengalami disleksia di SDN 1 Sangsit yaitu :

1.Prevensi Disleksia yaitu upaya-upaya prevensi disleksia itu lebih ditekankan pada melatih anak untuk meningkatkan Phonic dan Phonemic awareness yaitu hal yang terpenting untuk menstimulasi anak agar tidak mengalami risiko kesulitan belajar membaca,dan perlu diterapkan sejak dini sekali.

3.Intervensi disleksia yaitu upaya yang dilakukan dengan tujuan anak menguasai :

1. Kesadaran fonologi

2. Asosiasi suara dan simbol

3. Program terorganisir simbol suara yang diajarkan secara sistematis
4. Silabisasi

5. Morfologi

6. Sintaks

7. Pemahaman bacaan

8. Kelancaran membaca

3. Clinical Teaching yaitu upaya yang dilakukan pada taraf observasi

4. Remidial teaching upaya dilakukan khusus yang mengalami disleksia

5.Kompensasi, Dispensasi dan Toleransi

6. Alat bantu

7.Upaya memperhatikan perkembangan sosial emosional anak

Penelitian yang telah dilaksanakan di SDN 1 Sangsit Kecamatan Sawan telah berjalan dengan baik, mesti ada sedikit kendala dan hambatan, namun dapat dimaklumi, dari hasil penelitian yang telah dilakukan dengan melakukan Observasi, Wawancara,serta dokumentasi telah memberikan jawaban deskriptif terhadap rumusan masalah yang telah diajukan dalam penelitian.Berdasarkan hasil analisis diatas menunjukkan bahwa belum ada pemahaman yang ditunjukkan pada orang tua terhadap anakknya yang tergolong berkebutuhan khusus sangat rendah terbukti dengan orang tua yang kurang memberikan perhatian pengawasan, serta kasih sayang, anak yang mengalami kesulitan membaca .

\section{PENUTUP}

\section{KESIMPULAN}

Berdasarkan penelitian yang penulis lakukan terkait " Kesulitan membaca kata anak disleksia usia 7-12 tahun di SDN 1 Sangsit Kecamatan Sawan Kabupaten Buleleng dapat di simpulkan bahwa pertama tahap mengidentifikasi siswa disleksia dapat dilakukan dengan 1) mencari kesulitankesulitan yang dialami siswa disleksia, 2 ) mencari penyebab kendala-kendala yang dialami siswa disleksia , 3) mencari solusi untuk menangani siswa yang mengalami disleksia. 
Kedua, adapun upaya guru dalam membimbing anak yang mengalami disleksia dengan memahami keadaan anak Membangun rasa percaya diri dan melatih terus untuk membaca. Adapun treatment yang dilakukan oleh guru untuk anak disleksia yaitu motivasi ,pendampingan, penggunaan metode,penggunaan media, dan penyederhanaan bahasa.

Ketiga , dampak dari upaya guru terhadap kemampuan membaca anak telah mengalami peningkatan.Anak telah mampu membaca dengan sedikit lancar dibandingkan dengan pada saat pra penelitian yang dilakukan oleh peneliti. Bahkan salah satu dari ketujuh penderita disleksia ini sudah bisa membaca tanpa pendampingan khusus oleh guru.

\section{SARAN}

Dengan tidak mengurangi rasa hormat penulis, kepada pihak-pihak yang telah memberikan kontribusi dalam penelitian yang penulis lakukan tentang " kesulitan membaca kata anak disleksia usia 7-12 tahun di SDN 1 Sangsit Kecamatan Sawan Kabupaten Buleleng Bali,maka dengan segenap kerendahan hati ,penulis memberikan saran kepada beberapa pihak sebagai berikut :

\section{Kepala Sekolah}

Sebagai pimpinan yang juga memiliki tugas sebagai fasilitator dan mediator diharapkan kepala sekolah menyediakan pembelajaran tambahan seperti les untuk siswa disleksia khusus les membaca dan fasilitas lain yang mendukung untuk siswa disleksia dengan perlakuan istimewa. Sehingga anak yang mengalami disleksia dapat diatasi sedini mungkin dengan tepat sasaran.

2. Guru Kelas

Dalam membimbing anak disleksia guru telah berperan cukup baik. Namun disleksia sebagai kebutuhan khusus dan berpengaruh terhadap kelanjutan pembelajaran anak, membutuhkan metode-metode pembelajaran yang khusus dalam pembimbingannya.Sehingga disarankan guru mampu mengusai dan menerapkan metode-metode khusus untuk disleksia itu sendiri seperti metode fonic dan metode multisensori . jika metode-metode tersebut diterapkan,maka kemungkinan anak lancar membaca tidak membutuhkan waktu yang lama.

$$
\text { Daftar Pustaka }
$$

Biklen, Sari Knopp and Casella. 2007. A Practical Guide to Qualitative Dessertation. New York : Teachers College Press

Black,T.1993. Evaluating Social Science Research. London : Sage.

Bogdan, Robert C and Biklen, Sari Knopp. 1982. Qualitative Research for Education : An Intruduction to theory and Methods.

Bacon: Allyn and Bacon, Inc.

-1990. Riset Kualitatif untuk Pendidikan : Pengantar ke Teory dan Metode. Terjemahan Munandir. Jakarta : Proyek Pengembangan Pusat Fasilitas Bersama Antar Universitas / IUC ( Bank Dunia XVII)

--------.2006. Qualitative Reseach for Education: An Intruduction to Theory and Methods . Boston: Person.

Borgantti, Steve.2005. Intruduction to Grounded Theory

.http://www.analytictech.com/mb870/intro toGT.htm

Emsir.2008. Metodologi Penelitian Pendidikan :Kuantitatif dan kualitatif. Jakarta: Rajawali Pers.

Dumont,J.J.1994.Dyslexie, theorie, diagnost iek,behandeling,

Rotterdam: Lemniscaat b.v. Dumont,J.J.1985.Leerstoornissen,Diagnost iek en behandeling,

Deel 1. Rotterdam: Lemniscaat b.v. Moleong, Lexy J. 2001. Metodologi Penelitian Kualitatif. Bandung: Remaja Rosdakarya. 